\title{
骨代謝とプロスタグランディン(PG)（第 2 報）
}

\author{
——骨粗鬆症に対する $\mathrm{PGE}_{1}(\mathrm{OP}$ 1206) の効果—
}

\author{
東島利夫 ・ 山根 徹・松下和子・橋本博史 $\cdot$ 塩川優-*
}

\begin{abstract}
Study of prostaglandin on bone metabolism; effect of $P G E_{1}$ (OP 1206) on osteoporosis

Toshio Tohjima - Toru Yamane - Kazuko Matsusita • Hiroshi Hashimoto, Yuichi Shiokawa*
\end{abstract}

1970年, Klein および Raisz ${ }^{1) か ゙ ~ p r o s t a g l a n d i n ~(P G) ~}$ E は骨吸収を促進すると報告して以来，14年経過してい るが，骨代謝と PG との関連性については，まだ不明 な点が多い。すなわち, 悪性腫瘍 ${ }^{2)}$, 骨䯣炎 ${ }^{3)}$, 関節りウ マチ4)など，骨吸収を伴う炎症の際には，PG 産生が立 進しているところから，PG には骨吸収の促進作用があ ることが強調されてきた。 これに対して，1979年 Yonaga ${ }^{5)}$ は, $\mathrm{PGE}_{1}$ にはカルシトニン様作用があり, 骨吸 収を抑制することを報告し，1981年 ${ }^{\circ} \mathrm{Katz}^{6}$ ) $\mathrm{PGE}_{1}$ の 前駆物質である $\gamma$-リノレン酸を投与すると骨吸収が抑制 されることを報告して扣り，in vivo では $\mathrm{PGE}_{1}$ が骨吸 収を抑制する可能性が示唆された。

さらに1984年 Chyun7) in vitro に打いても, PGE がステロイドによる骨吸収促進作用に拮抗することを報 告している.

このように最近, PGE, 特に $\mathrm{PGE}_{1}$ には骨吸収を阻 止する作用があるとの報告が目立ってきた，従来の報告 との矛盾について, Chyun は, 従来の実験では in vivo における PG 濃度に比べ, はるかに高い濃度の PG が 使用されたためであろらと推論している.

一方, 骨粗鬆症の治療については, 活性型ビタミンD $\left[1,25(\mathrm{OH})_{2} \mathrm{D}_{3}\right]$ の投与が有望であるとされているが, まだ確固たる治療法はない，特に膠原病などの慢性炎症 性疾患では，ステロイド剂の使用が不可欠な場合が多い

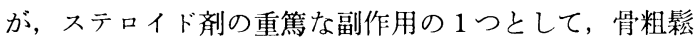
症があり，それに伴ら疼痛，骨折などが併発により患者 に大きな苦痛を与えている。亦た，糖尿病患者にも骨粗 鬆症はしばしばみられ，患者の大きな負担の 1 つになっ ている.

これらの観点から，われわれは，骨粗鬆症を有する糖 尿病患者に $\mathrm{PGE}_{1}$ と同様な生物学的活性を有する $\mathrm{PGE}_{2}$

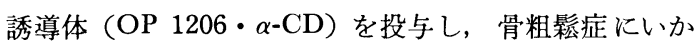

\footnotetext{
* Department of Internal Medicine, Juntendo University School of Medicine 順天堂大学医学 部内科学教室
}

なる影響を及ぼすかを検討した。

\section{対 象}

骨粗鬆症を有する糖尿病患者 16 人. 男性 12 , 女性 4 . 年龄38〜79歳, 平均56.4歳である. 対照は, 骨粗鬆症を 有する糖尿病患者 28 人. 男性 16 , 女性 12 . 年㛔 $36 \sim 85$ 歳, 平均57.1歳である。

\section{万 法}

対象に $\mathrm{PGE}_{1}$ 誘導体 $\left[\mathrm{OP} 1206\left(\mathrm{PGE}_{1}-\alpha-\mathrm{CD}: 10 \mu \mathrm{g}\right.\right.$ /錠), 小野]を経口的に 3 錠/日, 分 3 で投与し, 前, 2 力月, 4 力月, 6 力月にマイクロデンシトメーター (MD) 法により，第 2 中手骨の骨萎縮度の測定を行っ た。 な扣，骨粗鬆症の判定は1ＭCI（骨皮質幅指数）, (2) d (骨髄質幅)，(3) GSmin [(骨皮質十骨髄質) の密度 の指標], (4) GSmax (骨皮質部分のみの密度の指標), (5) $\Sigma G S / D$ (単位長さ当たりの骨密度の指標), (6)骨パター ン (骨の状態の指標), (7) 重症度総合判定（1)～(6)の指 標の值から総合的に判定), にそれぞれ区分し行った. なお，対照群には OP 1206 を投与せす，定期的に MD 法により骨萎縮度を测定した。

\section{成 績}

今回の成績は途中経過の報告であり最終結果ではな い.したがって，まだ OP 1206 の投与期間はバラつき が多く 1 力月以内 4 人, $1 \sim 2$ 力月 5 人, $3 \sim 4$ 力月 4 人, 5 〜 6 月 3 人であるため, 対照群との投与日数別 の有意差検定は行っていない.今回は有効性の大まかな 目安をつけるために, OP 1206 投与前値之投与後の值 ( $1 \sim 6$ 力月間の平均値) により, 増加, 不変, 減少の 3 群に区分し $\chi^{2}$ 検定を行った.

(1) MCI：前值に比べ, 0.01 以上の変動を示したもの を増加または減少，0.009 以下のものを不変とすると， 対照群は, 増加 8 人 $(29 \%)$, 不変 8 人 $(29 \%)$, 低下 12 人 $(43 \%)$. 一方, OP 1206 投与群は, 増加 6 人 (46\%), 不変 3 人 $(23 \%)$, 低下 4 人 $(31 \%)$ であり, OP 1206 投与群は, 対照群に比べ MCI の増加例が不変および 低下例に比し有意に認められた（P<0.05, $\chi^{2}$-test）（図 1 左).

(2) $\mathrm{d}$ : 前值に比べ 0.1 以上の変動を示したものを増 

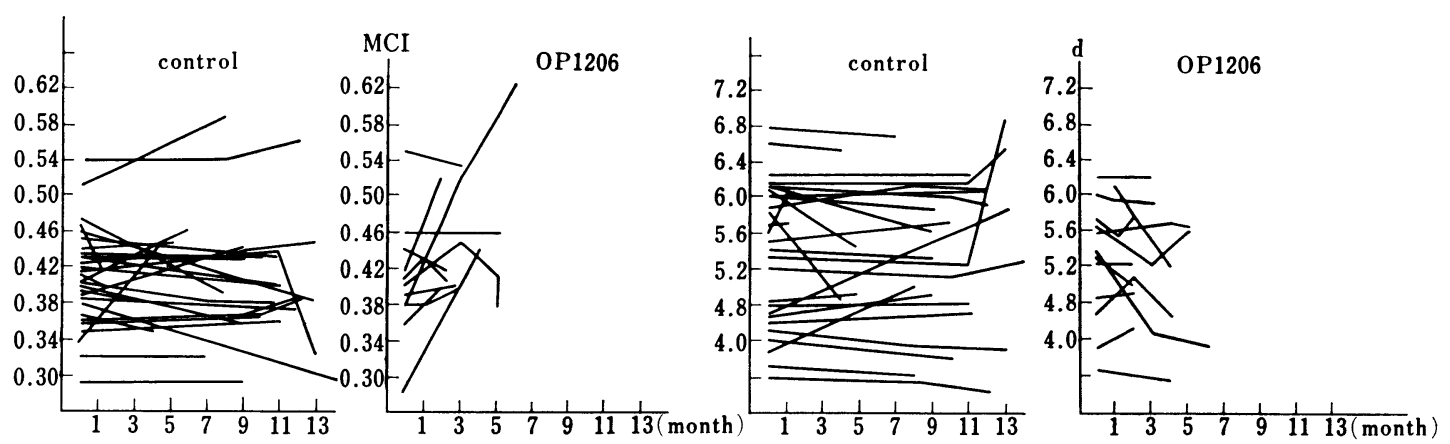

図 1 effect of OP 1206 on bone metabolism in diabetics with osteoporosis
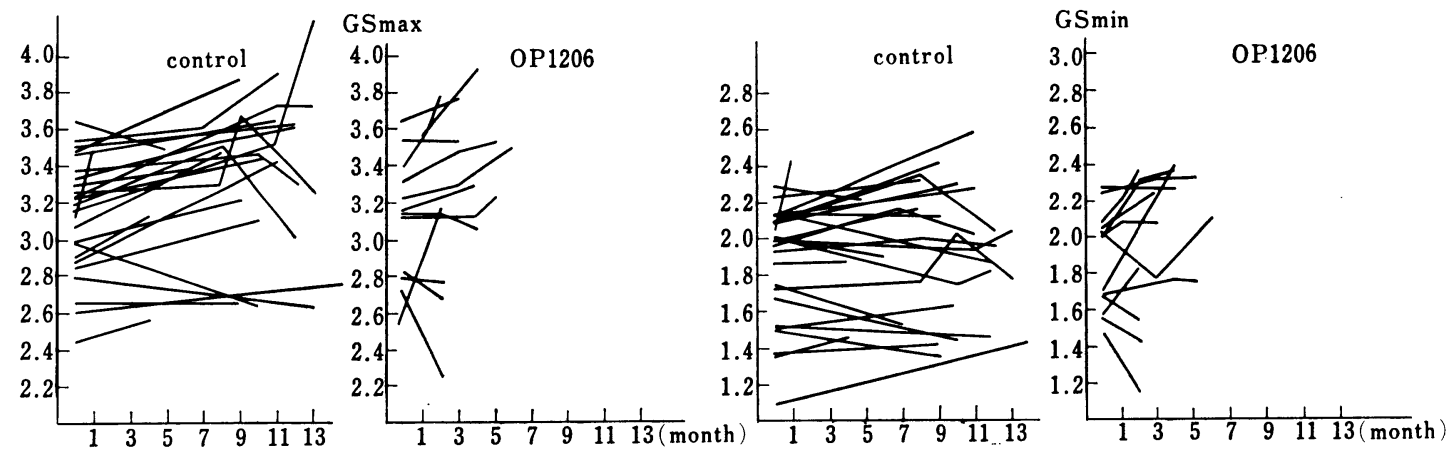

図 2 effect of OP 1206 on bone metabolism in diabetics with osteoporosis
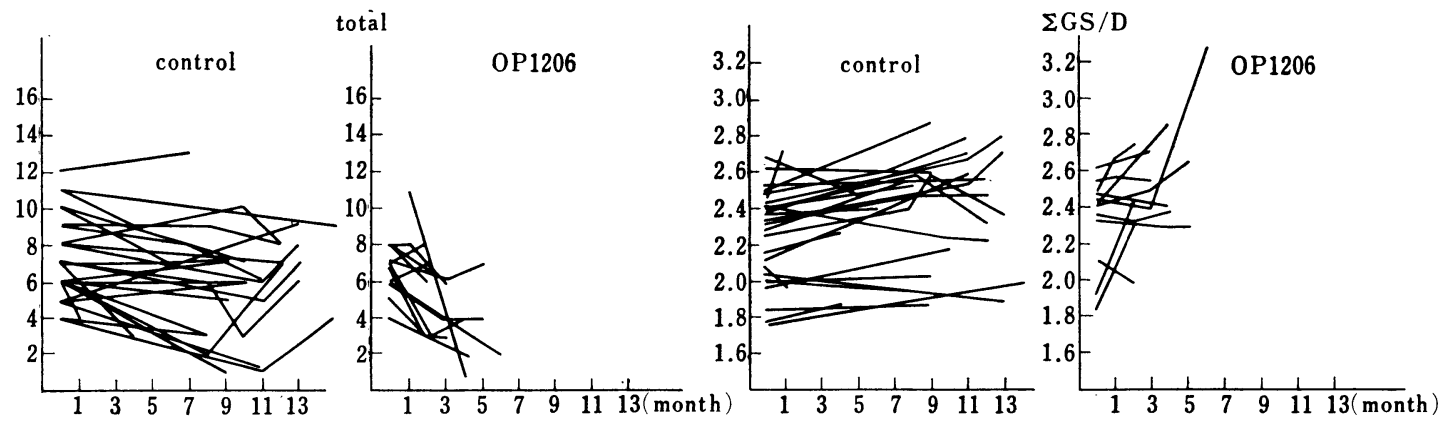

図 3 effect of OP 1206 on bone metabolism in diabetics with osteoporosis

加または減少，0.09以下のものを不変とすると，対照群 は増加 10 人 $(38 \%)$, 不変 8 人 $(31 \%)$, 低下 8 人 $(31 \%)$ であった。一方，OP 1206 投与群は，増加 2 人 (15\%), 不変 5 人 $(38 \%)$ ，低下 6 人 $(46 \%)$ であり，対照群に 比べ OP 1206 投与群は低下例が多い傾向がみられた (図 1 右).

(3) GSmax : 前值に比べ0.1以上の変動を増加 または 不変, 0.09 以下の変動を不変とすると, 対照群は, 増加 16 人 $(57 \%)$, 不変 7 人 $(25 \%)$, 低下 5 人 $(18 \%)$. 一 方, OP 1206 投与群は, 増加 8 人 $(62 \%)$, 不変 4 人 (31 $\%$ ，低下 2 人 $(15 \%)$ であり，対照群と比較して有意 な変動はみられなかった（汹 2 左）。
(4) GSmin : 前值に比べ 0.1 以上の変動を増加または 不変, 0.09 以下の変動を不変とすると, 対照群は, 増加 16 人 $(57 \%)$, 不変 7 人 $(35 \%)$, 低下 5 人 $(18 \%)$. 一 方, OP 1206 投与群は, 増加 5 人 $(39 \%)$, 不変 5 人 (39 $\%)$, 低下 3 人 $(23 \%)$ であり，対照群に比べ増加例が 少ない傾向がみられた（図 2 右）.

(5) $\sum \mathrm{GS} / \mathrm{D}$ : 前值に比べ 0.1 以上の変動を増加また は低下とし，0.09 以下の変動を不変とすると，対照群 は, 増加 17 人 $(61 \%)$, 不変 6 人 $(21 \%)$, 低下 5 人 $(18$ $\%$ ），一方，OP 1206 投与群は，増加 6 人 (46\%), 不変 5 人 $(38 \%)$, 低下 2 人 $(15 \%)$ であり, 両群のあいだ に有意な変動差は認めなかった（図 3 右）. 
(6) 重症度総合判定 : 前值に比べ 1 以上の変動を増加 または減少とし，0.9 以下の変動を不変とすると，対照 群は, 増加 6 人 $(21 \%)$, 不変 6 人 $(21 \%)$, 低下 16 人 $(57 \%)$ ，一方，OP 1206 投与群は，増加 2 人 (15\%), 不変 1 人 $(8 \%)$, 低下 10 人 $(77 \%)$ であり, 対照群に 比べ低下例が多い傾向がみられた（因 3 左）.

\section{考 察}

OP $1206 \cdot \alpha-\mathrm{CD}$ と $\mathrm{PGE}_{1}$ 誘導体で，代謝酵素（15hydroxyprostaglandin dehydrogenase) によって不活性 化されないため, 経口的に投与可能の薬剂であり，血中 に扎いて $\mathrm{PGE}_{1}$ と同様の生物学的活性を有することが 確認されている。 また，その有効投与量も，1日3錠 (30 $\mu \mathrm{g})$ で十分であるとされている。 したがって， OP 1206 の投与による病態の変化は， $\mathrm{PGE}_{1}$ 投与とほぼ同一. 視してよいと考えられる。一方，推計学的にみると，今 回の成績は中間報告であり，OP 1206 の投与期間がま だ短い症例が多く, OP 1206 投与群と対照群との投与期 間別の比較検討は行っていない。したがって，今回の成 績は，どこまでも参考值である。しかしながら，OP 1206 投与群が $\sum$ GS/D の低下をきたさず，逆に MCI すなわち骨皮質幅の増加をきたし，骨粗鬆症の重症度も 改善する傾向がみられた。 また，骨塩量を投影するとさ れている $\sum \mathrm{GS} / \mathrm{D}$ の有意な増加は認めなかったが，有 意な低下もなく，骨吸収の促進を思わせる所見はみられ なかった。

今回のわれわれの中間成績は Chyun の in vitro の成 績を裏づけたものであり，Yonaga の動物実験の成績と も一致している。むろん，今回の成績だけで $\mathrm{PGE}_{1}$ には 骨粗鬆症の改善作用があると速断するのは危険である が，少なくとも 1 日 $30 \mu \mathrm{g}$ の OP 1206 を 6 カ月間
連用しても骨粗鬆症が悪化しないことは確認できた。だ が，その治療効果については，さらに長期間の follow 必要である.

\section{結 論}

$\mathrm{PGE}_{1}$ 誘導体である OP $1206 ・ \alpha-\mathrm{CD}$ を骨粗鬆症を 有する糖尿病患者に， $1 \sim 6$ 力月間連続投与 し， MCI の増加と, 骨粗鬆症の重症度の改善傾向を認めた。

\section{文 献}

1) Klein, D.A., Raisz, L.G.: Stimulation of bone resorption in tissue culture. Endocrinology 86: 1436, 1970.

2) Tashimian, A.H., Jr.: Role of prostaglandins in the production of hypercalcemia by tumors. Cancer Res. 38: 4138, 1978.

3) Harris, M., Jenkins, M.V., Bennet, A., Wills, M.R.: Prostaglandin production and bone resorption by dental cysts. Nature 245: 213, 1973.

4) Robinson, D.R., Tashjian, H., Jr., Levine, L.: Prostaglndin-stimulated bone resorption by rheumatoid synovia (A posible mechanism for bone destruction in rheumatoid arthritis). J. Clin. Invest. 56: 1181, 1975.

5) Yonaga, T., Morimoto, S.: A calcitonin-like action of prostaglandin $E_{1}$. Prostaglandins $17(6)$ : 801, 1979.

6) Katz, J.M., Wilson, T., Skinner, S.J.M., Gray, D.H.: Bone resorption and prostaglandin production by mouse Calvari in vitro; responce to exogenous prostaglandins and their precursor fatty acid. Prostaglandins 22(4): 537, 1981.

7) Chyun, Y.S., Raisz L.G.: Stimulation of bone formation by prostaglandin E. Prostaglandin 27(1): 97, 1984 . 